\title{
Performance, nutritional behavior, and metabolic responses of calves supplemented with forage depend on starch fermentability
}

\author{
S. Mojahedi, ${ }^{*}$ M. Khorvash, ${ }^{11}$ G. R. Ghorbani, ${ }^{*}$ E. Ghasemi, ${ }^{*}$ M. Mirzaei, $†$ and F. Hashemzadeh-Cigari ${ }^{*}$ \\ ${ }^{*}$ Department of Animal Science, College of Agriculture, Isfahan University of Technology, Isfahan 84156-83111, I. R. Iran \\ †Department of Animal Science, Faculty of Agriculture and Natural Resources, Arak University, Arak 38156-88349, Iran
}

\begin{abstract}
This study evaluated the interactive effects of forage provision on performance, nutritional behavior, apparent digestibility, rumen fermentation, and blood metabolites of dairy calves when corn grains with different fermentability were used. Sixty 3-d-old Holstein calves were randomly assigned to 1 of 4 treatments in a $2 \times 2$ factorial arrangement. Dietary treatments were (1) steam-flaked (SF) corn without alfalfa hay (AH) supplementation (SF-NO), (2) SF corn with AH supplementation (SF-AH), (3) cracked (CR) corn without $\mathrm{AH}$ supplementation (CR-NO), and (4) CR corn with $\mathrm{AH}$ supplementation (CR-AH). All calves received the same amount of pasteurized whole milk and weaned on d 56 of the experiment; the study was terminated on d 70. Steam-flaked corn contained higher amounts of gelatinized starch in comparison with cracked corn (44.1 vs. $12.5 \%$ of total starch, respectively). Starter intake was not affected by corn processing methods or $\mathrm{AH}$ provision during the pre- or postweaning periods. However, we noted an interaction between corn processing methods and forage supplementation for starter intake during d 31 to 50 of the experiment, where calves fed on SF-AH starter had greater starter intake than those fed SF-NO starter, but the starter intake was not different between CR-NO and CR-AH fed calves. Furthermore, $\mathrm{AH}$ increased average daily gain (ADG) of calves fed an SF-based diet but not in calves fed a CR-based diet during the preweaning and overall periods. Interaction between forage provision and time was significant for ADG and feed efficiency, as calves supplemented with forage had higher ADG (0.982 vs. 0.592, respectively) and feed efficiency compared with forage unsupplemented calves at the weaning week. Forage supplementation resulted in more stable ruminal condition compared with nonforage-fed calves, as evidenced by higher
\end{abstract}

Received September 7, 2017.

Accepted January 3, 2018.

${ }^{1}$ Corresponding author: khorvash@cc.iut.ac.ir ruminal $\mathrm{pH}$ (5.71 vs. 5.29 , respectively) at postweaning and lower non-nutritive oral behavior around weaning time ( 55 vs. 70.5 min, respectively). The concentration of blood $\beta$-hydroxybutyrate was also greater in calves supplemented with forage than in unsupplemented calves. Results of the present study indicated that performance response and skeletal growth were the same between 2 corn processing methods. Forage provision improved ADG of calves fed the SF-based diet, but not the CR-based diet throughout the study.

Key words: calf, cracking, forage provision, steam flaking

\section{INTRODUCTION}

In neonatal calves, physical and metabolic development of rumen is an important factor for soft transition from preruminant to functioning solid-fed ruminants (Khan et al., 2016), which can improve efficiency of solid feed utilization and ultimately performance and general health status (Drackley, 2008). Many factors, such as the nature of the offered solid feed (Khan et al., 2011), may affect rumen development by inducing early establishment of a microbial ecosystem (Baldwin et al., 2004), enhancing ruminal fermentation products (i.e., VFA), and triggering rumen epithelium development. Because of limited starch digestion in corn, various methods of processing, such as steam flaking, steam rolling, dry rolling, and grinding, are normally applied to improve digestibility at periweaning period (Lesmeister and Heinrichs, 2004). However, data suggested that over-processed grains and extensive gelatinization of starch or large amounts of fine particles may trigger rapid ruminal acid production and disturb ruminal fermentation (Lesmeister and Heinrichs, 2004; Suárez et al., 2006), which can cause lower performance responses of calves (Lesmeister and Heinrichs, 2004). Previously, Porter et al., (2007) reported that providing calves with concentrate feeds containing adequate large particles ( $75 \%$ of particles of starter $>1.19 \mathrm{~mm}$ ), such as coarse mashed corn with a mean particle size of approximately $2 \mathrm{~mm}$ or greater, could improve ruminal health, which 
cause more ADG and solid feed intake as compared a pelleted fine particle diet. However, overall gastrointestinal starch digestion in cracked corn without heat processing is relatively low, reducing starch utilization efficiency (NRC, 2001). In this regard, an appropriate grain processing method, such as steam flaking with gelatinization of starch, may maintain good ruminal health (Bateman et al., 2009) and optimize ruminal and postruminal digestion (Zinn et al., 2002); however, to some extent, feeding young calves with steam-flaked corn yielded conflicting results. Moeini et al. (2017) reported that steam flaking of equal combination of corn and barley increased the feed efficiency as well as ADG of dairy calves as compared with ground or pelleted grains in the starter. In contrast, Lesmeister and Heinrichs (2004) reported that calves fed steam-flaked corn had lower ADG, starter intake, and feed efficiency as compared with whole or dry-rolled corn grain, which may indicate that this processing method needs more supportive effective fiber from forage sources to maintain ruminal $\mathrm{pH}$ in normal range. However, Bateman et al. (2009) observed that feeding steam-flaked corn showed the same response as calves fed on whole corn or dry-rolled corn. Part of this discrepancy might be related to the level of corn processing, processing condition (steaming time and flaking density), and, more importantly, balance between physically effective fiber and carbohydrate sources in starter diets (Owens et al., 1997; Khan et al., 2016). To our knowledge, little information is available regarding the comparison of steam-flaked and cracked corn with particle size near the recommended coarseness $(2 \mathrm{~mm})$.

It has been well described that forage provision to neonatal calves stabilizes ruminal environment and $\mathrm{pH}$ by acting as a stimulator of chewing activity and rumen muscularization, as well as maintaining ruminal papillae functionality (Beiranvand et al., 2014b; Mirzaei et al., 2015), resulting in the improvement of feed consumption and growth performance (Castells et al., 2012; Montoro et al., 2013; Beiranvand et al., 2014b; EbnAli et al., 2016). Yet, 2 questions persist: (1) Does increasing the rate of starter particle size to approximately 2 $\mathrm{mm}$ with no forage suffice to maintain ruminal health as well as improve performance responses in highly processed corn; and (2) How do young calves respond to forage provision with a high proportion of starter coarse particle size originating from different type of processing? It has been reported that calves fed diets containing rolled corn exhibited more ADG than those fed on ground corn, and 2 other treatments containing 7.5 or $15 \%$ of grass hay had higher ADG as well as improved feed efficiency than rolled corn (Coverdale et al., 2004). Therefore, in diets containing a high propor- tion of overprocessed grain, it is necessary to supply sufficient physically effective particles from forage or nonforage sources to stimulate chewing activity and saliva production of dairy calves, as observed in adult cattle.

The response of dairy calves to supplemental alfalfa hay (AH) might be different from their response to cracked (CR) corn with low fermentable starch or steam-flaked (SF) corn with extended fermentable starch; therefore, the objective of our study was to investigate the interactive effects of 2 different processing methods, including cracking or steam flaking with different extents of ruminal fermentability and $\mathrm{AH}$ provision in the starter diet on performance, skeletal growth, nutritional behavior, apparent digestibility, rumen fermentation, and blood metabolites of dairy calves.

\section{MATERIALS AND METHODS}

The study was carried out at the facilities of a local dairy farm (Ghiam Esfahan Plantation and Domesticated Co., Isfahan, Iran). It had been previously approved by the Animal Care and Use Committee of the Iranian Council of Animal Care (1995).

\section{Animals, Management, and Experimental Design}

Holstein calves $(41.4 \pm 2.39 \mathrm{~kg}$ of $\mathrm{BW}$; mean $\pm \mathrm{SD})$ were separated from their dams at birth, weighed, and transferred to individual pens $(1.2 \times 2.5 \mathrm{~m})$ bedded with sand that was replaced every 24 or $48 \mathrm{~h}$ as needed. They were fed $4 \mathrm{~L}$ of colostrum within $6 \mathrm{~h}$ of birth and colostrum feeding continued for the first $2 \mathrm{~d}$ of their lives. Blood samples were taken by venipuncture from the jugular vein at $24 \mathrm{~h}$ after the first colostrum intake, and serum total protein was determined as an indicator of passive transfer of immunity using a Reichert AR200 digital hand-held refractometer (Reichert Inc., Depew, NY). Only calves having a serum protein level $>6 \mathrm{~g} /$ $\mathrm{dL}$ were included in the study. A total of sixty 3-d-old calves were enrolled in the study and were bucket-fed twice a day with pasteurized whole milk (at 0800 and 1800 h, 50\% each time) with an adjusted step up/step down milk feeding protocol with $4 \mathrm{~L} / \mathrm{d}$ milk from $\mathrm{d} 1$ to $14,5 \mathrm{~L} / \mathrm{d}$ milk from d 15 to $21,7 \mathrm{~L} / \mathrm{d}$ milk from d 22 to $42,5 \mathrm{~L} / \mathrm{d}$ milk from d 43 to $50,2 \mathrm{~L} / \mathrm{d}$ milk from d 51 to 53 , and $1 \mathrm{~L} / \mathrm{d}$ milk from d 54 to 56 of the study; all calves were weaned at $56 \mathrm{~d}$ of experiment.

Calves ( $\mathrm{n}=15,8$ males and 7 females) were randomly assigned to 4 treatments in a $2 \times 2$ factorial arrangements with the factors of alfalfa hay inclusion as a forage source (0 or $10 \%$ on DM basis) and the corn processing as sole source of grain in the starter (SF vs. 
Table 2. In situ ruminal starch disappearance and particle size distribution (mean \pm SD) of experimental diets containing either steam-flaked $(\mathrm{SF})$ or cracked $(\mathrm{CR})$ corn with $(\mathrm{AH})$ or without $(\mathrm{NO})$ alfalfa hay

\begin{tabular}{|c|c|c|c|c|c|}
\hline Item & $\mathrm{SF}-\mathrm{NO}$ & $\mathrm{SF}-\mathrm{AH}$ & CR-NO & $\mathrm{CR}-\mathrm{AH}$ & $\mathrm{AH}$ \\
\hline \multicolumn{6}{|c|}{ In situ ruminal disappearance, $\%$ of total starch } \\
\hline $8 \mathrm{~h}$ & $73.7 \pm 3.58$ & $75.7 \pm 3.23$ & $65.5 \pm 3.76$ & $64.4 \pm 4.69$ & - \\
\hline \multicolumn{6}{|c|}{ Particle size distribution, $\mathrm{mm}$ pore size, $\%$ of $\mathrm{DM}$} \\
\hline $4.75 \mathrm{~mm}$ & $45.6 \pm 2.17$ & $10.6 \pm 1.26$ & $29.5 \pm 3.61$ & $13.0 \pm 0.84$ & $3.3 \pm 0.85$ \\
\hline $2.36 \mathrm{~mm}$ & $22.2 \pm 0.80$ & $30.0 \pm 1.18$ & $23.5 \pm 0.03$ & $32.7 \pm 1.58$ & $24.8 \pm 1.12$ \\
\hline $0.3 \mathrm{~mm}$ & $6.7 \pm 0.32$ & $10.8 \pm 0.18$ & $8.7 \pm 1.38$ & $10.3 \pm 0.68$ & $18.2 \pm 1.95$ \\
\hline $0.15 \mathrm{~mm}$ & $2.6 \pm 0.67$ & $2.8 \pm 0.99$ & $1.9 \pm 1.33$ & $3.5 \pm 0.71$ & $8.2 \pm 1.04$ \\
\hline Pan & $0.2 \pm 0.19$ & $0.2 \pm 0.19$ & $0.3 \pm 0.24$ & $0.3 \pm 0.17$ & $1.1 \pm 0.28$ \\
\hline$>2.36$ & $67.8 \pm 2.32$ & $40.6 \pm 1.41$ & $53.4 \pm 3.86$ & $45.7 \pm 1.75$ & $28.1 \pm 2.98$ \\
\hline$>1.18$ & $82.1 \pm 2.49$ & $67.0 \pm 1.10$ & $71.3 \pm 3.63$ & $67.3 \pm 1.67$ & $46.7 \pm 2.26$ \\
\hline GMPL, ${ }^{1} \mathrm{~mm}$ & $2.13 \pm 0.083$ & $1.21 \pm 0.020$ & $1.58 \pm 0.157$ & $1.27 \pm 0.015$ & $0.85 \pm 0.09$ \\
\hline
\end{tabular}

${ }^{1}$ Geometric mean particle length.

AOAC, 1990). Total solid concentration of milk samples were used for total DMI calculation.

Before the experiment initiation, alfalfa hay was chopped (Golchin Trasher Hay Co., Isfahan, Iran). At least 8 representative samples of starter were collected from each treatment throughout the experiment and were used for particle size distribution. Particle size distribution of 4 experimental diets and $\mathrm{AH}$ were measured by dry sieving using an automatic vibratory sieve shaker (model 120; Techno Khak, Khavaran, Tehran, Iran) with 4.75-, 2.36-, 1.18-, 0.6-, 0.3-, and 0.15-mmdiameter screens (Table 2). Precisely $100 \mathrm{~g}$ of sample was placed in duplicate on the top screen and the stack of sieves was shaken until the distribution of materials did not change (approximately $10 \mathrm{~min}$ ). Geometric mean particle size was calculated as described by ASAE (1983). In diets containing forage, 10\% AH was uniformly mixed with the concentrate portion of the diet and offered as a total mixed ration. Calves had free access to diets and clean water in the 2 separate buckets throughout the experiment.

\section{Ruminal In Situ Starch Degradability}

To measure in situ ruminal starch degradability, triplicate samples of diet $(0.5 \mathrm{~g})$ were weighed into Ankom F57 filter bags (25 mm pore size; Ankom Technology Corp., Macedon, NY). Thirty-six bags were filled, put into 2 larger loose mesh cloth sacks $(30 \times 40 \mathrm{~cm} ; 2 \mathrm{~mm}$ pore size), and incubated in the 2 ruminally fistulated nonlactating Holstein cows for 8, 12, and $24 \mathrm{~h}$. The cows were individually housed in $4 \times 4 \mathrm{~m}$ covered pens, where they received a diet consisting of $40 \%$ maize silage, $20 \%$ lucerne hay, $10 \%$ barley straw, and 30\% concentrate (corn grain, soybean meal, wheat bran, and a mineral/vitamin mix). After incubation, the bags were removed from the rumen, hand-washed with cold water until the rinsing water was clear, and dried at $65 \mathrm{C}$ for $48 \mathrm{~h}$ in a forced-air oven.

\section{Measurements, Sampling, and Analyses}

All calves were fed the offered milk with no refusals. Starter intake was measured every morning. Calves were weighed at d $0,10,20,30,40,50,56,63$, and 70 of the experiment with an electronic balance. Average daily gain and feed efficiency ( $\mathrm{kg}$ of $\mathrm{BW}$ gain $/ \mathrm{kg}$ of total DMI) were calculated for preweaning, postweaning, and the overall experimental period. Blood samples were obtained at d 35 and 70 of the study by venipuncture of the jugular vein into an evacuated tube (Becton-Dickinson, Franklin Lakes, NJ) containing clot activator $3 \mathrm{~h}$ after morning feeding and immediately placed on ice. Tubes were centrifuged at $2,000 \times g$ for $15 \mathrm{~min}$ at $4^{\circ} \mathrm{C}$ to separate the serum, which was then stored at $-20^{\circ} \mathrm{C}$ for subsequent analysis. Serum glucose level were determined by an automated biochemical analyzer (Technicon RA1000; Bayer Corp., Tarrytown, NY) using commercial kit (Pars Azmoon Co., Tehran, Iran) according to the manufacturer's protocol [glucose oxidase-phenol 4-aminoantipyrine peroxidase (GODPAP) method]. Serum concentrations of BHB were determined by enzymatic analysis (DRG Co., Marburg, Germany; Iwersen et al., 2009). Intra- and interassay coefficients of variation for the BHB assay were 2.9 and $3.6 \%$, respectively.

Ruminal fluid was obtained $4 \mathrm{~h}$ after morning starter feeding with a stomach tube fitted to a vacuum pump on d 35 and 70 of the study. A sample of the fresh rumen liquid was used for $\mathrm{pH}$ measurement (HI 8318, Hanna Instruments, Cluj-Napoca, Romania). Four milliliters of the rumen fluid for stabilization was then 
acidified with $1 \mathrm{~mL}$ of $25 \%$ metaphosphoric acid and stored $\left(-20^{\circ} \mathrm{C}\right)$ until analysis for VFA by GC, as described by Hashemzadeh-Cigari et al. (2014).

In addition, body measurements including body length (distance between the points of shoulder and rump), body girth (the measurement of the distance around the belly over the part of the back before morning feeding), withers height (distance from base of the front feet to the withers), heart girth (circumference of the chest), hip height (distance from base of the rear feet to hook bones), and hip width (distance between the points of hook bones) of the calves were recorded at the start, weaning (d 56), and at the end of the study (d 70) according to the method described by Khan et al. (2007).

Behavior was monitored by direct observations for all animals once a week for 2 wk before and 2 wk after weaning. Animals were observed for $3 \mathrm{~h}$ immediately following the morning feeding; therefore, total observation time per animal was $12 \mathrm{~h}$ for the entire monitoring period. Calves were observed every minute and the observer recorded the occurrence of lying (no chewing activity), standing (no chewing activity), eating feed, ruminating (either lying or standing), and non-nutritive oral behaviors (when the animal licked any surface or tongue rolled; Terré et al., 2013).

\section{Statistical Analysis}

Body weight, starter feed intake, ADG, and gain-tofeed ratio (G:F) data were analyzed using the MIXED procedure of SAS (version 9.2, SAS Institute Inc., Cary, $\mathrm{NC}$ ) with repeated measures for the preweaning (from d 1 to 56 of the study), postweaning (from d 57 to 70 of the study), and overall (from d 1 to 70 ) periods. The statistical model that was applied included the effects of processing method, forage provision, sex, period, and their 2 and 3-way interactions as fixed effects and calf within treatment as a random effect. Initial values of body measurements were considered as covariate for the body measurements analysis. Model for apparent nutrient digestibility, behavioral data, and skeletal growth data included the processing method, forage provision, and their interaction. The latter model was used for ruminal fermentation parameters and blood metabolites but the effects of sampling time (d 35 and 70 of study) were included in the model. A covariance structure was chosen based on best Akaike information criterion and Bayesian information criteria indexes. Autoregressive (1) was found to be the most appropriate for all variables. When differences were detected for treatments or interactions, means separation analysis was conducted using a Tukey's adjustment for the probability. Significance was declared at $P<0.05$ and trends were considered when $0.05<P<0.10$.

\section{RESULTS}

Table 1 shows the chemical composition of the different starter diets. As indicated, dietary CP was similar across starter diets, whereas the concentration of starch and NDF differed among treatments. Starch concentration was lower but NDF content was greater in forage containing diets. Table 2 shows the in situ ruminal starch degradability and particle size distributions of diets. Steam flaking of corn resulted in higher ruminal starch degradability compared with cracked corn. The SF-NO starter diet had the greatest amount of particles retained on the top screens (i.e., $4.75-\mathrm{mm}$ screen), resulting in the greatest geometric mean particle length (GMPL) of $2.13 \mathrm{~mm}$. The CR-NO diet was intermediate in GMPL of $1.58 \mathrm{~mm}$ followed by 2 other AH-containing starters, which had more particles retained on the second, third, and fourth screens (i.e., $2.36,1.18$, and $0.6 \mathrm{~mm}$, respectively) with GMPL of 1.21 and $1.27 \mathrm{~mm}$, respectively. Only SF-NO starter had more than $80 \%$ of the particles retained on the screen with $1.18-\mathrm{mm}$ opening size, but other starters had marginally lower cumulative proportion of particles retained on 1.18-mm screen. Particles retained on the top screen were predominantly coarse fragments of corn grain with a very low amount of $\mathrm{AH}$ particles, as $\mathrm{AH}$ particles passed to the below screens, which contained greater amounts of forage fiber.

\section{Intake and Growth Performance}

Starter intake, ADG, and feed efficiency data are reported in Table 3. Starter intake was similar between calves fed CR- or SF-based diets during the pre- and postweaning periods. However, a tendency of interaction between corn processing methods and forage supplementation $(P<0.10)$ was observed in starter intake during d 31 to 50 of the experiment, as calves fed SF-AH had greater starter intake than those fed SF-NO starter. Furthermore, we noted an interaction between corn processing methods and forage provision at d 11 to $30(P<0.05)$ whereby calves fed CR-NO had greater starter intake than those fed CR-AH, but we found no difference between calves fed SF-AH and SF-NO. Total DMI as a percentage of BW were not affected by corn processing method, forage provision, or their interaction. Moreover, interactions were observed between forage supplementation and corn processing methods for ADG, as AH increased ADG of calves fed an SF-based diet $(P<0.05)$ but not in calves receiv- 
Table 3. Effects of corn processing (P) method [steam flaked (SF) or cracked (CR)] and alfalfa hay provision [alfalfa hay (AH), or no alfalfa hay $(\mathrm{NO})$ ] on intake, $\mathrm{ADG}$, feed efficiency, and BW of dairy calves ( $\mathrm{n}=15$ calves per treatment)

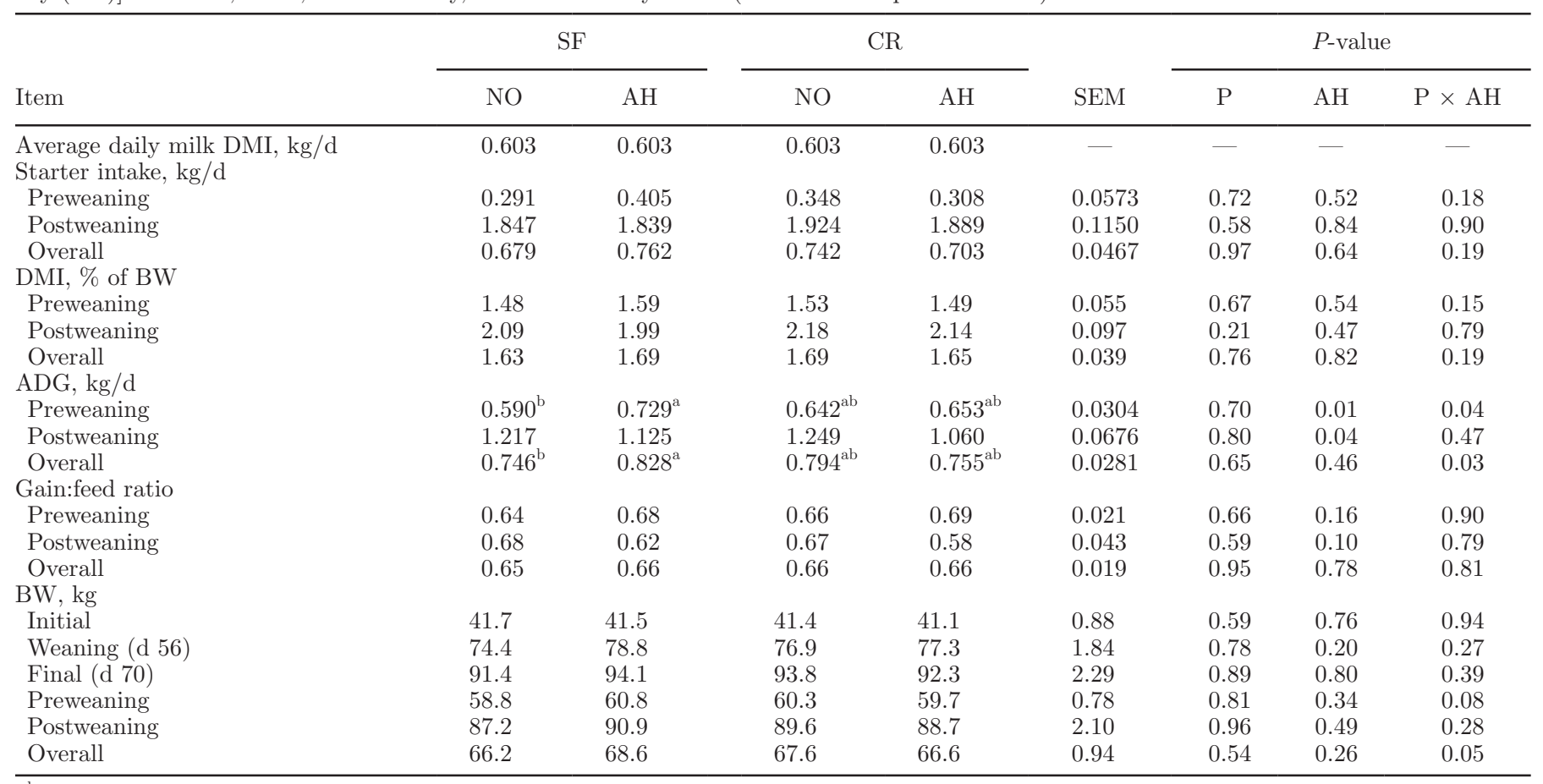

${ }^{\mathrm{a}, \mathrm{b}}$ Means within a row with different superscripts are significantly different $(P<0.05)$.

ing a CR-based diet during both the preweaning and overall periods.

An interaction between forage offering and time on ADG and G:F were observed, whereby forage-fed calves, regardless of corn processing effect, had greater ADG $(0.982$ vs. 0.592 , respectively; $P<0.01)$ and improved G:F ratio (0.714 vs. 0.514 , respectively; $P<$ 0.05) as compared with those fed no forage the week of weaning. However, during the last week of experiment, calves not offered with forage had a sharp increase in ADG even more than forage-supplemented calves $(P<$ 0.05). Body weight of calves was not affected by corn processing method or forage feeding during experimental period, but their interaction was significant during preweaning and overall periods, as calves fed SF-AH starter tended to have greater BW than those fed SF$\mathrm{NO}$ starter, but BW of calves fed $\mathrm{Cr}-\mathrm{AH}$ or $\mathrm{Cr}-\mathrm{NO}$ did not differ.

\section{Skeletal Growth}

Results of body measurements, including body length, heart girth, body barrel, withers height, hip height, and hip width at weaning day and end of experiment, are shown in Table 4. These results showed that none of the body measurements was affected by corn processing method, forage provision, or their interactions.

\section{Nutritional Behavior}

Table 5 presents the total time devoted to performing each recorded behavior of calves at 2 wk before and 2 wk after weaning. Corn processing method, forage provision, or their interaction did not affect time devoted to standing, lying, and eating $(P>0.10)$. Regardless of the effects of corn processing method, ruminating time tended to increase ( 48.5 vs. 38.5 , respectively; $P<$ $0.10)$, but non-nutritional behaviors tended to decrease (55.0 vs. 70.5 ; respectively; $P<0.10$ ) in calves supplemented with forage as compared with unsupplemented calves.

\section{Nutrient Digestibility}

Results of nutrient digestibility at the end of experiment are shown in Table 6. Some interactions were observed between processing methods and forage supplementation on apparent digestibility values of DM $(P<$ $0.05)$, OM $(P<0.10)$, and NDF $(P<0.01)$, whereby $\mathrm{CR}-\mathrm{AH}$ resulted in the lowest value in nutrient digestibility. Cracking corn as compared with steam flaking, as well as supplementing forage as compared with no forage, resulted in greater $\mathrm{CP}$ digestibility $(P<0.01)$. The greatest value of $\mathrm{CP}$ digestibility was observed in calves fed the CR-AH diet. 
Table 4. Effects of corn processing (P) method [steam flaked (SF) or cracked (CR)] and alfalfa hay provision [alfalfa hay $(\mathrm{AH})$ or no alfalfa hay $(\mathrm{NO})$ ] on skeletal growth of dairy calves

\begin{tabular}{|c|c|c|c|c|c|c|c|c|}
\hline \multirow[b]{2}{*}{ Item } & \multicolumn{2}{|c|}{$\mathrm{SF}$} & \multicolumn{2}{|c|}{$\mathrm{CR}$} & \multirow[b]{2}{*}{ SEM } & \multicolumn{3}{|c|}{$P$-value } \\
\hline & NO & $\mathrm{AH}$ & $\mathrm{NO}$ & $\mathrm{AH}$ & & $\mathrm{P}$ & $\mathrm{AH}$ & $\mathrm{P} \times \mathrm{AH}$ \\
\hline \multicolumn{9}{|c|}{ Body length, cm } \\
\hline Initial & 44.5 & 44.5 & 44.4 & 44.0 & 0.60 & 0.57 & 0.73 & 0.73 \\
\hline Weaning & 53.4 & 54.2 & 53.4 & 53.2 & 0.57 & 0.42 & 0.58 & 0.39 \\
\hline Final & 55.0 & 53.7 & 54.9 & 55.0 & 0.53 & 0.24 & 0.25 & 0.23 \\
\hline \multicolumn{9}{|c|}{ Heart girth, cm } \\
\hline Initial & 80.7 & 81.0 & 81.2 & 81.6 & 0.83 & 0.52 & 0.69 & 0.93 \\
\hline Weaning & 99.9 & 99.9 & 99.8 & 98.6 & 0.89 & 0.43 & 0.50 & 0.50 \\
\hline Final & 105.5 & 105.7 & 104.4 & 103.6 & 1.00 & 0.11 & 0.76 & 0.58 \\
\hline \multicolumn{9}{|c|}{ Body barrel, cm } \\
\hline Initial & 82.2 & 81.6 & 80.8 & 82.0 & 1.00 & 0.65 & 0.79 & 0.41 \\
\hline Weaning & 107.0 & 109.3 & 107.6 & 107.6 & 1.75 & 0.74 & 0.51 & 0.50 \\
\hline Final & 121.2 & 120.4 & 120.0 & 119.4 & 1.83 & 0.55 & 0.72 & 0.93 \\
\hline \multicolumn{9}{|c|}{ Withers height, cm } \\
\hline Initial & 78.4 & 79.4 & 78.0 & 78.0 & 0.57 & 0.27 & 0.15 & 0.68 \\
\hline Weaning & 89.4 & 89.4 & 90.6 & 83.9 & 2.72 & 0.42 & 0.23 & 0.22 \\
\hline Final & 92.3 & 92.4 & 92.0 & 91.2 & 0.67 & 0.28 & 0.59 & 0.54 \\
\hline \multicolumn{9}{|c|}{ Hip height, cm } \\
\hline Initial & 80.2 & 81.2 & 80.4 & 79.8 & 0.55 & 0.30 & 0.76 & 0.16 \\
\hline Weaning & 91.1 & 92.5 & 92.2 & 92.6 & 0.56 & 0.69 & 0.35 & 0.81 \\
\hline Final & 94.1 & 93.4 & 93.2 & 93.2 & 0.60 & 0.38 & 0.59 & 0.62 \\
\hline \multicolumn{9}{|c|}{ Hip width, cm } \\
\hline Initial & 19.0 & 18.8 & 19.1 & 19.3 & 0.55 & 0.84 & 0.84 & 0.33 \\
\hline Weaning & 23.7 & 24.2 & 24.1 & 24.0 & 0.33 & 0.30 & 0.32 & 0.36 \\
\hline Final & 26.2 & 26.3 & 26.1 & 26.1 & 0.31 & 0.71 & 0.90 & 0.90 \\
\hline
\end{tabular}

\section{Ruminal Fermentation Parameters}

Results of ruminal fermentation parameters measured at d 35 and 70 are shown in Table 7. Results showed no interactions between corn processing methods and forage supplementation with respect to VFA concentration, molar percentage of individual VFA, acetate-to-propionate ratio, and ruminal $\mathrm{pH}$ at $\mathrm{d} 35$ and 70 of the experiment. Ruminal $\mathrm{pH}$ was greater in AH-supplemented calves than in unsupplemented calves at $d 70$ of the experiment. The same amount of total VFA concentration in the rumen among foragesupplemented or unsupplemented calves was observed.

Ruminal fermentation parameters were the same between 2 processing methods of corn at d 35 and 70 of the experiment. However, molar percentage of propionate (39.4 vs. 41.5 , respectively; $P<0.05$ ) was lower and that of acetate ( 50.8 vs. 48.2 , respectively) tended to be greater in calves supplemented with forage compared with calves offered no forage at d 70 of the experiment. The molar percentage of isovalerate $(0.525$ vs. 0.645 , respectively) tended to be lower in forage supplemented compared with forage unsupplemented calves at $\mathrm{d} 70$ of the experiment.

\section{Blood Metabolites}

Blood metabolites data are shown in Table 8. We found an interaction between corn processing methods and forage provision on blood glucose concentration at $\mathrm{d} 70$ of experiment. This interaction indicated that calves receiving CR-AH starter had lower glucose concentration than those receiving CR-NO starter. Calves fed SF-based diets tended to have greater BHB concen-

Table 5. Effects of corn processing (P) method [steam flaked (SF) or cracked (CR)] and alfalfa hay provision [alfalfa hay $(\mathrm{AH})$ or no alfalfa hay $(\mathrm{NO})]$ on nutritional behavior of dairy calves

\begin{tabular}{|c|c|c|c|c|c|c|c|c|}
\hline \multirow[b]{2}{*}{ Item } & \multicolumn{2}{|c|}{$\mathrm{SF}$} & \multicolumn{2}{|c|}{$\mathrm{CR}$} & \multirow[b]{2}{*}{ SEM } & \multicolumn{3}{|c|}{$P$-value } \\
\hline & $\mathrm{NO}$ & $\mathrm{AH}$ & $\mathrm{NO}$ & $\mathrm{AH}$ & & $\mathrm{P}$ & $\mathrm{AH}$ & $\mathrm{P} \times \mathrm{AH}$ \\
\hline Standing, min & 222 & 242 & 224 & 243 & 13 & 0.92 & 0.15 & 0.96 \\
\hline Lying, min & 315 & 329 & 327 & 302 & 26 & 0.78 & 0.83 & 0.44 \\
\hline Eating, min & 68 & 59 & 67 & 65 & 8 & 0.76 & 0.47 & 0.64 \\
\hline Ruminating, min & 38 & 46 & 39 & 51 & 7 & 0.65 & 0.07 & 0.65 \\
\hline Non-nutritive oral behavior, min & 77 & 51 & 64 & 59 & 10 & 0.82 & 0.09 & 0.30 \\
\hline
\end{tabular}


Table 6. Effects of corn processing (P) method [steam flaked (SF) or cracked (CR)] and alfalfa hay provision [alfalfa hay $(\mathrm{AH})$ or no alfalfa hay $(\mathrm{NO})]$ on apparent nutrient digestibility of dairy calves

\begin{tabular}{|c|c|c|c|c|c|c|c|c|}
\hline \multirow[b]{2}{*}{ Digestibility, \% } & \multicolumn{2}{|c|}{$\mathrm{SF}$} & \multicolumn{2}{|c|}{$\mathrm{CR}$} & \multirow[b]{2}{*}{ SEM } & \multicolumn{3}{|c|}{$P$-value } \\
\hline & $\mathrm{NO}$ & $\mathrm{AH}$ & $\mathrm{NO}$ & $\mathrm{AH}$ & & $\mathrm{P}$ & $\mathrm{AH}$ & $\mathrm{P} \times \mathrm{AH}$ \\
\hline DM & $81.5^{\mathrm{a}}$ & $78.8^{\mathrm{a}}$ & $79.1^{\mathrm{a}}$ & $71.5^{\mathrm{b}}$ & 1.12 & $<0.01$ & $<0.01$ & 0.04 \\
\hline $\mathrm{OM}$ & 82.9 & 79.7 & 80.0 & 73.0 & 1.15 & $<0.01$ & $<0.01$ & 0.09 \\
\hline $\mathrm{CP}$ & 65.7 & 74.8 & 73.5 & 80.9 & 1.43 & $<0.01$ & $<0.01$ & 0.56 \\
\hline NDF & $61.0^{\mathrm{a}}$ & $58.6^{\mathrm{a}}$ & $63.2^{\mathrm{a}}$ & $49.2^{\mathrm{b}}$ & 2.03 & 0.07 & $<0.01$ & $<0.01$ \\
\hline
\end{tabular}

${ }^{\mathrm{a}, \mathrm{b}}$ Means within a row with different superscripts are significantly different $(P<0.05)$.

tration than CR-based diets at $\mathrm{d} 35$ of the experiment (0.087 vs. 0.071 , respectively; $P=0.10)$. Regardless of corn processing method, forage inclusion in the starter diet resulted in greater BHB concentration than diets without forage at $\mathrm{d} 35$ of the experiment $(0.097 \mathrm{vs}$. 0.061, respectively; $P<0.01)$.

\section{DISCUSSION}

Recently, in a meta-analysis study, it was reported that the effects of forage provision to dairy calves on performance responses may depend on the physical form of starter, as starter intake or ADG improved in response of forage provision in ground or pelleted starter compared with texturized starters (Imani et al., 2017). It has been reported that with similar ingredients of starter feed, processing grain to have a significant amount of fine particles may disrupt rumen epithelial health and reduce feed intake and ADG in dairy calves (Beharka et al., 1998; Bateman et al., 2009). Porter et al., (2007) reported that calves offered with starter diets containing more than $80 \%$ particles greater than 1.19 $\mathrm{mm}$ and mean particle size of approximately $2 \mathrm{~mm}$ had improved intake and ADG without any physiological abnormalities as compared with pelleted starter. In another study, calves fed starters containing steam-flaked corn grain, despite having more than $90 \%$ particle size greater than $1.18 \mathrm{~mm}$, showed lower intake, ADG, and disturbed feed efficiency, indicating that particles $>1.18$ $\mathrm{mm}$ originating from nonforage sources in extensively processed corn-based diets failed to maintain ruminal health and performance (Lesmeister and Heinrichs, 2004). In our experiment, corn was incorporated in the starter as the sole grain source in the form of SF or

Table 7. Effects of corn processing (P) method [steam flaked (SF) or cracked (CR)] and alfalfa hay provision [alfalfa hay $(\mathrm{AH})$ or no alfalfa hay $(\mathrm{NO})]$ on ruminal fermentation of dairy calves

\begin{tabular}{|c|c|c|c|c|c|c|c|c|}
\hline \multirow[b]{2}{*}{ Item } & \multicolumn{2}{|c|}{$\mathrm{SF}$} & \multicolumn{2}{|c|}{ CR } & \multirow[b]{2}{*}{ SEM } & \multicolumn{3}{|c|}{$P$-value } \\
\hline & $\mathrm{NO}$ & $\mathrm{AH}$ & $\mathrm{NO}$ & $\mathrm{AH}$ & & $\mathrm{P}$ & $\mathrm{AH}$ & $\mathrm{P} \times \mathrm{AH}$ \\
\hline \multicolumn{9}{|c|}{ Ruminal pH } \\
\hline d 35 & 5.72 & 5.71 & 5.61 & 5.77 & 0.15 & 0.81 & 0.81 & 0.62 \\
\hline d 70 & 5.35 & 5.77 & 5.24 & 5.66 & 0.10 & 0.51 & 0.01 & 0.99 \\
\hline \multicolumn{9}{|c|}{ Total VFA, mmol/L } \\
\hline d 35 & 105.6 & 103.4 & 104.9 & 105.3 & 1.24 & 0.60 & 0.46 & 0.31 \\
\hline d 70 & 104.6 & 105.7 & 103.8 & 103.9 & 0.94 & 0.19 & 0.55 & 0.61 \\
\hline \multicolumn{9}{|c|}{ VFA, mol/100 mol } \\
\hline \multicolumn{9}{|c|}{ Acetate } \\
\hline d 35 & 51.0 & 49.3 & 51.2 & 53.4 & 2.45 & 0.38 & 0.90 & 0.43 \\
\hline d 70 & 46.4 & 49.1 & 50.1 & 52.6 & 1.50 & 0.87 & 0.10 & 0.57 \\
\hline \multicolumn{9}{|c|}{ Propionate } \\
\hline d 35 & 41.5 & 40.9 & 39.7 & 37.2 & 2.47 & 0.27 & 0.54 & 0.70 \\
\hline d 70 & 42.1 & 40.2 & 40.1 & 38.7 & 0.80 & 0.62 & 0.01 & 0.86 \\
\hline \multicolumn{9}{|c|}{ Butyrate } \\
\hline d 35 & 7.4 & 9.6 & 9.1 & 9.3 & 1.19 & 0.59 & 0.31 & 0.40 \\
\hline d 70 & 11.5 & 10.4 & 8.9 & 8.6 & 1.04 & 0.15 & 0.74 & 0.87 \\
\hline \multicolumn{9}{|c|}{ Isovalerate } \\
\hline d 35 & 1.2 & 1.3 & 0.7 & 1.3 & 0.27 & 0.48 & 0.28 & 0.45 \\
\hline d 70 & 0.4 & 0.5 & 0.8 & 0.5 & 0.12 & 0.36 & 0.06 & 0.13 \\
\hline \multicolumn{9}{|c|}{ Valerate } \\
\hline d 35 & 3.2 & 4.2 & 3.7 & 2.6 & 0.73 & 0.22 & 0.54 & 0.52 \\
\hline d 70 & 3.5 & 3.7 & 3.6 & 2.4 & 0.63 & 0.32 & 0.59 & 0.42 \\
\hline \multicolumn{9}{|c|}{ Acetate:propionate } \\
\hline d 35 & 1.24 & 1.47 & 1.30 & 1.46 & 0.21 & 0.90 & 0.38 & 0.89 \\
\hline d 70 & 1.15 & 1.24 & 1.25 & 1.47 & 0.16 & 0.32 & 0.34 & 0.67 \\
\hline
\end{tabular}


Table 8. Effects of corn processing (P) method [steam flaked (SF) or cracked (CR)] and alfalfa hay provision [alfalfa hay $(\mathrm{AH})$ or no alfalfa hay $(\mathrm{NO})]$ on blood metabolites of dairy calves

\begin{tabular}{|c|c|c|c|c|c|c|c|c|}
\hline \multirow[b]{2}{*}{ Item } & \multicolumn{2}{|c|}{$\mathrm{SF}$} & \multicolumn{2}{|c|}{$\mathrm{CR}$} & \multirow[b]{2}{*}{ SEM } & \multicolumn{3}{|c|}{$P$-value } \\
\hline & $\mathrm{NO}$ & $\mathrm{AH}$ & NO & $\mathrm{AH}$ & & $\mathrm{P}$ & $\mathrm{AH}$ & $\mathrm{P} \times \mathrm{AH}$ \\
\hline \multicolumn{9}{|l|}{ Glucose, $\mathrm{mg} / \mathrm{dL}$} \\
\hline d 70 & $87.5^{\mathrm{ab}}$ & $87.4^{\mathrm{ab}}$ & $100.1^{\mathrm{a}}$ & $79.6^{\mathrm{b}}$ & 4.05 & 0.60 & 0.01 & 0.02 \\
\hline \multicolumn{9}{|l|}{ ВHB } \\
\hline d 35 & 0.06 & 0.11 & 0.06 & 0.08 & 0.009 & 0.10 & $<0.01$ & 0.13 \\
\hline d 70 & 0.24 & 0.27 & 0.23 & 0.28 & 0.040 & 0.98 & 0.43 & 0.74 \\
\hline
\end{tabular}

${ }^{\mathrm{a}, \mathrm{b}}$ Means within a row with different superscripts are significantly different $(P<0.05)$.

CR. Both processed corn diets contained a high amount of coarse particles (more than $67 \%$ of particles greater than $1.18 \mathrm{~mm}$ ) but SF corn had considerable amount of gelatinized starch ( $44.1 \%$ of total starch), resulting in more starch ruminal fermentability (Richards and Hicks, 2007). This extent of gelatinization is close to optimum degree of gelatinization for starch digestion (Matsushima, 2006). Despite increasing feed utilization efficiency, such a great level of fermentable starch necessitates more effective sources of particles to prevent rumen acidosis and epithelial parakeratosis to ultimately enhance ruminal VFA absorption (Coverdale et al., 2004).

In the present experiment, calves offered $\mathrm{AH}$ with SF-based diets, but not CR-based diets, showed an improvement in starter DMI and ADG at preweaning period. These interactions could confirm our hypothesis that forage provision may differently affect performance of dairy calves with marginally sufficient coarse particles but different starch fermentability. As SF-NO starter had higher levels of readily fermentable starch and insufficient effective fiber, it possibly induced acidosis in the rumen and lowered starter intake as compared with SF-AH starter. Forage provision to SF-based diets may improve ruminal condition and starter intake. In agreement with our results, Mirzaei et al. (2016) reported that corn silage supplementation to calves fed SF corn in a texturized diet enhanced starter feed intake (1.04 vs. $0.54 \mathrm{~kg} / \mathrm{d}$ ) and ADG (0.611 vs. $0.442 \mathrm{~kg} / \mathrm{d}$ ) as compared with calves fed SF corn in a texturized diet without forage. Furthermore, early in life, forage addition to the CR-based diets had an adverse effect on starter intake, but this response was not observed in SF-based diets. These results are in agreement with results of Maktabi et al., (2016), who observed calves supplemented with $\mathrm{AH}$ in CR-based diets tended to have lower starter intake compared with calves offered no forage throughout the experimental period. The adverse effects of forage supplementation in CR-based diets might be attributed to the gut fill effects due to the lower rate and extent of ruminal digestion of feed components, including fragmented corn particles as well as forage fiber, in undeveloped rumen of calves at early ages. However, lower starter intake resulting from feeding forage in the CR-based diet was not reflected in preweaning ADG of calves. As described by Owens et al. (1986), cracked corn provides more intestinally absorbable starch with higher energetic efficiency than ruminally fermented starch, which is likely to compensate the lower intake or digestibility of forage provided by CR-based diets.

It has been reported that a smooth transition from liquid feed to solid feed is important in minimizing weight loss and distress at weaning (Weary et al., 2009). In our experiment, forage-fed calves had greater ADG (39\%) and G:F (28\%) as compared with those fed no forage at week of weaning. These results clearly indicate that calves offered with forage experienced lower weaning distress and smoothly passed this critical period. These calves had lower non-nutritive oral behavior as a behavioral indicator of weaning stress as described by Eckert et al. (2015). Regarding the same feed intake among treatments around weaning, disturbed performance responses in calves not supplemented with forage could be partially attributed to unstable ruminal environment, as shown by lower ruminal $\mathrm{pH}$ at postweaning as well as more energy expenditure for alleviating weaning stress. However, during the last week of experiment, calves not offered forage had a sharp increase in ADG compared to forage-supplemented calves $(P<0.05)$, but the potential mechanisms that elicit the compensatory growth improvements of ADG were not clear. In line with our results, Daneshvar et al. (2017) reported that calves fed a diet containing $24 \% \mathrm{CP}$ by a conventional milk feeding method showed a lag in weight gain during the weaning period and then a sharp improvement in weight gain, which resulted in the greatest ADG in this treatment compared with other treatments at the postweaning period.

Consistent with our results, the effects of various kinds of corn or other grains processing had minor or no effects on skeletal growth parameters, as reported 
in other studies (Ghassemi Nejad et al., 2012; Terré et al., 2015; Mirzaei et al., 2016). Results of body measurements herein are in agreement with others, who found that most skeletal growth parameters were similar in calves supplemented with or without forage in starter diet (Beiranvand et al., 2014a; Mirzaei et al., 2017). However, in contrast to our results, it has been reported that heart girth and body barrel were lower (Maktabi et al., 2016) or higher (Daneshvar et al., 2015) in calves receiving $\mathrm{AH}$ compared with those not receiving hay. These results indicate that, in the current study, different amounts of nutrient intake and digestibility due to processing or forage inclusion resulted in improved weight gain other than skeletal (bone deposition) growth.

The greater ruminating time but lower non-nutritional behaviors in response to forage supplementation compared with nonsupplemented calves are in agreement with the results of Terré et al. (2013) and Castells et al. (2012), who reported that the provision of forage as $\mathrm{AH}$ or oat hay reduced non-nutritive oral behavior and increased ruminating time in young calves. As described by Miller-Cushon and DeVries (2015), some feeding behavior may directly affect performance and health of the dairy calf, and learned behavior patterns may persist and affect welfare over a longer period of time. As discussed, in the current experiment, improved performance of calves supplemented with forage at weaning can be partly attributed to the observed lower non-nutritive oral behavior of calves as an indicators of good welfare.

As expected, diets containing SF resulted in more apparent DM, OM, and NDF digestibility than CR. Johnson et al. (1968) showed that steers fed diets containing more than 70\% DM of CR corn had lower DM digestibility than those fed the same diet but with SF corn. In another study, it was reported that feedlot cattle fed on diets containing SF corn had higher DM, $\mathrm{OM}$, and starch digestibility as well as improved ADG as compared with dry-rolled corn processing (Corona et al., 2005), which might result from the extensive gelatinization and solubility of starch in the rumen and total gastrointestinal tract (Zinn et al., 2002). The lowest $\mathrm{DM}$ and $\mathrm{OM}$ digestion with the $\mathrm{CR}-\mathrm{AH}$ diet may be attributed to immature rumen function of calves at postweaning, which has failed to properly digest the supplemented forage with lower digestible nutrients compared with starter diet (Porter et al., 2007; Daneshvar et al., 2015), or the high amount of CR corn inclusion with lower digestibility than SF corn. In agreement with our results, it has been reported that calves given $\mathrm{AH}$ as free access choice (EbnAli et al., 2016) or in a TMR (Castells et al., 2012) had more CP digestibility than nonsupplemented calves.
Generally, ruminal $\mathrm{pH}$ is affected by the rate of VFA production and absorption, or the extent of saliva secretion as a natural buffer (Khan et al., 2016). With the same amount of total VFA concentration in the rumen among forage supplemented or unsupplemented calves, it is more probable that forage inclusion in the starter diet could encourage saliva production by more rumination. Also, forage provision may facilitate VFA clearance from the rumen by stimulating physical abrasion of feed particles on the rumen papilla and preventing parakeratosis of ruminal epithelium (Beiranvand et al., 2014b). Castells et al., (2013) reported that forage supplementation increased the expression of the monocarboxylate transporter-1 (as a VFA transporter) gene in the rumen epithelium, which may aid VFA absorption and stabilization of ruminal environment.

In the current experiment, molar percentage of propionate was lower and that of acetate was higher in calves supplemented with forage at d 70 of the experiment. In agreement with our results, previous studies demonstrated that forage intake stimulates fibrolytic microbial growth and results in a greater molar percentage of acetate at the expense of propionate in the rumen (Žitnan et al., 1998; Kim et al., 2016). Despite the fact that greater acetate production is associated with more normal rumen fermentation (Porter et al., 2007), as indicated by Calsamiglia et al. (2007), with the same amount of total VFA, greater acetate and lower propionate proportion may indicate less efficient ruminal fermentation and nutrients utilization; this was observed in the lower G:F of calves supplemented with forage at postweaning in the present experiment.

The molar percentage of isovalerate was lower in calves supplemented with forage at d 70 of the experiment. It has been well demonstrated that branchedchain VFA stimulates the growth of fibrolytic bacteria (Guilloteau et al., 1988). These fatty acids arise from the catabolism of AA (Val, Ile, Leu, and Pro) and are in turn used for the biosynthesis of those AA (Liu et al., 2009). Forage addition to starter diets may stimulate the growth of fibrolytic bacteria and, consequently, incorporate more isovalerate as a precursor of branchedchain AA to microbial protein biomass, resulting in lower isovalerate in the rumen fluid.

We found an interaction between corn processing methods and forage provision on blood glucose concentration at $\mathrm{d} 70$ of experiment. This interaction indicated that calves receiving CR-AH starter had lower glucose concentration than those receiving CR-NO starter. This interaction may be attributed to lower feed intake and nutrient digestibility in response of forage supplementation to a CR-based diet, which may cause lower ruminal propionate as glucose precursor production or direct intestinal glucose absorption. At d 35 of the our experi- 
ment, calves offered forage had greater concentrations of BHB compared with nonforage-fed calves, in agreement with Nemati et al. (2016), who reported that calves supplemented with forage had higher plasma BHB concentration than unsupplemented calves at d 70 of the experiment. Effects of forage on BHB concentration, as an indicator of metabolic functionality of rumen, were observed at an earlier age in our experiment (d 35 vs. 70 of the experiment, respectively) as compared with the experiment of Nemati et al. (2016), indicating a more developed rumen epithelium to metabolize final fermentation product in response of forage provision at early stage of life in the current study.

\section{CONCLUSIONS}

Results of the present study indicated that inclusion of chopped alfalfa hay to the either SF or CR diet resulted in increasing rumination time and lowering nonnutritive oral behavior, as well as possibly improving the ruminal environment, as observed by higher ruminal $\mathrm{pH}$ in these calves. Forage supplementation to calves fed the SF diet resulted in greater starch fermentability compared with CR, as well as improved growth performance at preweaning and overall. In other words, in the case of overprocessed corn grain and extensive starch gelatinization, more effective fiber from forage is necessary to maintain feed intake and growth performance, possibly promoting a more stable rumen environment.

\section{ACKNOWLEDGMENTS}

The authors are grateful to the Isfahan University of Technology (Isfahan, Iran) and Ghiam Esfahan Plantation and Domesticated Co. (Isfahan, Iran) for grant and financial support of this study. The authors express their appreciation to the farm staffs at Ghiam Esfahan Plantation and Domesticated Co., including B. Moshiri, H. Khoshakhlagh, A. Mohammadi, and A. Pazoki for their kind assistance and diligent animal care; and to A. M. Vatankhah, and H. Khoshouei (IUT, Isfahan, Iran) for their help in conducting this experiment.

\section{REFERENCES}

AOAC. 1990. Official Methods of Analysis. Assoc. Off. Anal. Chem., Rockville, MD.

American Society of Agricultural Engineers (ASAE). 1983. Method of determining and expressing fineness of feed materials by sievingASAE standards. Agricultural Engineers Yearbook of Standards. ASAE, St. Joseph, MI.

Baldwin, R. L., K. R. McLeod, J. L. Klotz, and R. N. Heitmann. 2004. Rumen development, intestinal growth and hepatic metabolism in the pre- and postweaning ruminant. J. Dairy Sci. 87:E55-E65.

Bateman, H. G., T. M. Hill, J. M. Aldrich, and R. L. Schlotterbeck. 2009. Effects of corn processing, particle size, and diet form on performance of calves in bedded pens. J. Dairy Sci. 92:782-789.
Beharka, A. A., T. G. Nagaraja, J. L. Morrill, G. A. Kennedy, and R. D. Klemm. 1998. Effects of form of the diet on anatomical, microbial, and fermentative development of the rumen of neonatal calves. J. Dairy Sci. 81:1946-1955.

Beiranvand, H., G. R. Ghorbani, M. Khorvash, and M. Kazemi-Bonchenari. 2014a. Forage and sugar in dairy calves' starter diet and their interaction on performance, weaning age and rumen fermentation. J. Anim. Physiol. Anim. Nutr. (Berl.) 98:439-445.

Beiranvand, H., G. R. Ghorbani, M. Khorvash, A. Nabipour, M. Dehghan-Banadaky, A. Homayouni, and S. Kargar. 2014b. Interactions of alfalfa hay and sodium propionate on dairy calf performance and rumen development. J. Dairy Sci. 97:2270-2280.

Calsamiglia, S., M. Busquet, P. W. Cardozo, L. Castillejos, and A. Ferret. 2007. Invited review: essential oils as modifiers of rumen microbial fermentation. J. Dairy Sci. 90:2580-2595.

Castells, L., A. Bach, G. Araujo, C. Montoro, and M. Terré. 2012. Effect of different forage sources on performance and feeding behavior of Holstein calves. J. Dairy Sci. 95:286-293.

Castells, L., A. Bach, A. Aris, and M. Terré. 2013. Effects of forage provision to young calves on rumen fermentation and development of the gastrointestinal tract. J. Dairy Sci. 96:5226-5236.

Corona, L., S. Rodriguez, R. A. Ware, and R. A. Zinn. 2005. Comparative effects of whole, ground, dry-rolled, and steam-flaked corn on digestion and growth performance in feedlot cattle. Prof. Anim. Sci. 21:200-206.

Coverdale, J. A., H. D. Tyler, J. D. Quigley III, and J. A. Brumm. 2004. Effect of various levels of forage and form of diet on rumen development and growth in calves. J. Dairy Sci. 87:2554-2562.

Daneshvar, D., M. Khorvash, E. Ghasemi, and A. H. Mahdavi. 2017. Combination effects of milk feeding methods and starter crude protein concentration: Evaluation on performance and health of Holstein male calves. Anim. Feed Sci. Technol. 223:1-12.

Daneshvar, D., M. Khorvash, E. Ghasemi, A. H. Mahdavi, B. Moshiri, M. Mirzaei, A. Pezeshki, and M. H. Ghaffari. 2015. The effect of restricted milk feeding through conventional or step-down methods with or without forage provision in starter feed on performance of Holstein bull calves. J. Anim. Sci. 93:3979-3989.

Drackley, J. K. 2008. Calf nutrition from birth to breeding. Vet. Clin. North Am. Food Anim. Pract. 24:55-86.

EbnAli, A., M. Khorvash, G. R. Ghorbani, A. H. Mahdavi, M. Malekkhahi, M. Mirzaei, A. Pezeshki, and M. H. Ghaffari. 2016. Effects of forage offering method on performance, rumen fermentation, nutrient digestibility and nutritional behavior in Holstein dairy calves. J. Anim. Physiol. Anim. Nutr. (Berl.) 100:820-827.

Eckert, E., H. E. Brown, K. E. Leslie, T. J. DeVries, and M. A. Steele. 2015. Weaning age affects growth, feed intake, gastrointestinal development, and behavior in Holstein calves fed an elevated plane of nutrition during the preweaning stage. J. Dairy Sci. 98:6315-6326.

Ghassemi Nejad, J., N. Torbatinejad, A. A. Naserian, S. Kumar, J. D. Kim, Y. H. Song, C. S. Ra, and K. I. Sung. 2012. Effects of processing of starter diets on performance, nutrient digestibility, rumen biochemical parameters and body measurements of Brown Swiss dairy calves. Asian-Aust. J. Anim. Sci. 25:980-987.

Guilloteau, P., F. Masoero, and O. Curto. 1988. The effect of isoacids on ruminal fermentation: in vitro trials. Reprod. Nutr. Dev. $28: 163-164$.

Hashemzadeh-Cigari, F., M. Khorvash, G. R. Ghorbani, M. Kadivar, A. Riasi, and Q. Zebeli. 2014. Effects of supplementation with a phytobiotics-rich herbal mixture on performance, udder health, and metabolic status of Holstein cows with various levels of milk somatic cell counts. J. Dairy Sci. 97:7487-7497.

Imani, M., M. Mirzaei, B. Baghbanzadeh-Nobari, and M. H. Ghaffari. 2017. Effects of forage provision to dairy calves on growth performance and rumen fermentation: A meta-analysis and metaregression. J. Dairy Sci. 100:1136-1150.

Iranian Council of Animal Care. 1995. Guide to the Care and Use of Experimental Animals, Vol. 1. Isfahan University of Technology, Isfahan, Iran.

Iwersen, M., U. Falkenberg, R. Voigtsberger, D. Forderung, and W. Heuwieser. 2009. Evaluation of an electronic cowside test to detect subclinical ketosis in dairy cows. J. Dairy Sci. 92:2618-2624. 
Johnson, D. E., J. K. Matsushima, and K. L. Knox. 1968. Utilization of flaked vs. cracked corn by steers with observations on starch modification. J. Anim. Sci. 27:1431-1437.

Khan, M. A., A. Bach, D. M. Weary, and M. A. G. von Keyserlingk. 2016. Invited review: Transitioning from milk to solid feed in dairy heifers. J. Dairy Sci. 99:885-902.

Khan, M. A., H. J. Lee, W. S. Lee, H. S. Kim, K. S. Ki, T. Y. Hur, G. H. Suh, S. J. Kang, and Y. J. Choi. 2007. Structural growth, rumen development, and metabolic and immune responses of Holstein male calves fed milk through step-down and conventional methods. J. Dairy Sci. 90:3376-3387.

Khan, M. A., D. M. Weary, and M. A. G. von Keyserlingk. 2011. Invited review: Effects of milk ration on solid feed intake, weaning, and performance in dairy heifers. J. Dairy Sci. 94:1071-1081.

Kim, Y.-H., N. Touji, K. Kizaki, S. Kushibiki, T. Ichijo, and S. Sato. 2016. Effects of dietary forage and calf starter on ruminal $\mathrm{pH}$ and transcriptomic adaptation of the rumen epithelium in Holstein calves during the weaning transition. Physiol. Genomics 48:803-809.

Lesmeister, K. E., and A. Heinrichs. 2004. Effects of corn processing on growth characteristics, rumen development, and rumen parameters in neonatal dairy calves. J. Dairy Sci. 87:3439-3450.

Liu, Q., C. Wang, Y. X. Huang, K. H. Dong, W. Z. Yang, S. L. Zhang, and H. Wang. 2009. Effects of isovalerate on ruminal fermentation, urinary excretion of purine derivatives and digestibility in steers. J. Anim. Physiol. Anim. Nutr. (Berl.) 93:716-725.

Maktabi, H., E. Ghasemi, and M. Khorvash. 2016. Effects of substituting grain with forage or nonforage fiber source on growth performance, rumen fermentation, and chewing activity of dairy calves. Anim. Feed Sci. Technol. 221:70-78.

Matsushima, J. K. 2006. History of feed processing. Pages 1-16 in Proc. Proc. Of Cattle Grain Processing Symposium. Oklahoma State University, Stillwater.

Miller-Cushon, E. K., and T. J. DeVries. 2015. Invited review: Development and expression of dairy calf feeding ehavior. Can. J. Anim. Sci. 95:341-350.

Mirzaei, M., M. Khorvash, G. R. Ghorbani, M. Kazemi-Bonchenari, and M. H. Ghaffari. 2017. Growth performance, feeding behavior, and selected blood metabolites of Holstein dairy calves fed restricted amounts of milk: No interactions between sources of finely ground grain and forage provision. J. Dairy Sci. 100:1086-1094.

Mirzaei, M., M. Khorvash, G. R. Ghorbani, M. Kazemi-Bonchenari, A Riasi, A. Nabipour, and J. J. G. C. van den Borne. 2015. Effects of supplementation level and particle size of alfalfa hay on growth characteristics and rumen development in dairy calves. J. Anim. Physiol. Anim. Nutr. (Berl.) 99:553-564.

Mirzaei, M., M. Khorvash, G. R. Ghorbani, M. Kazemi-Bonchenari, A. Riasi, A. Soltani, B. Moshiri, and M. H. Ghaffari. 2016. Interactions between the physical form of starter (mashed versus textured) and corn silage provision on performance, rumen fermentation, and structural growth of Holstein calves. J. Anim. Sci. 94:678-686.

Moeini, H., A. H. Mahdavi, A. Riasi, G. R. Ghorbani, E. Oskoueian, M. A. Khan, and M. H. Ghaffari. 2017. Effects of physical form of starter and forage provision to young calves on blood metabolites, liver composition and intestinal morphology. J. Anim. Physiol. Anim. Nutr. (Berl.) 101:755-766.
Montoro, C., E. K. Miller-Cushon, T. J. DeVries, and A. Bach. 2013 Effect of physical form of forage on performance, feeding behavior, and digestibility of Holstein calves. J. Dairy Sci. 96:1117-1124.

NRC. 2001. Nutrient Requirements of Dairy Cattle. 7th rev. ed. Natl. Acad. Press, Washington, DC.

Nemati, M., H. Amanlou, M. Khorvash, M. Mirzaei, B. Moshiri, and M. H. Ghaffari. 2016. Effect of different alfalfa hay levels on growth performance, rumen fermentation, and structural growth of Holstein dairy calves. J. Anim. Sci. 94:1141-1148.

Owens, F. N., D. S. Secrist, W. J. Hill, and D. R. Gill. 1997. The effect of grain source and grain processing on performance of feedlot cattle: A review. J. Anim. Sci. 75:868-879.

Owens, F. N., R. A. Zinn, and Y. K. Kim. 1986. Limits to starch digestion in the ruminant small intestine. J. Anim. Sci. 63:1634-1648.

Plascencia, A., and R. A. Zinn. 1996. Influence of flake density on the feeding value of steam-processed corn in diets for lactating cows. J. Anim. Sci. 74:310-316.

Porter, J. C., R. G. Warner, and A. F. Kertz. 2007. Effect of fiber level and physical form of starter on growth and development of dairy calves fed no forage. Prof. Anim. Sci. 23:395-400.

Richards, C. J., and B. Hicks. 2007. Processing of corn and sorghum for feedlot cattle. Vet. Clin. North Am. Food Anim. Pract. 23:207221.

Suárez, B. J., C. G. Van Reenen, W. J. J. Gerrits, N. Stockhofe, A. M. van Vuuren, and J. Dijkstra. 2006. Effects of supplementing concentrates differing in carbohydrate composition in veal calf diets: II. Rumen development. J. Dairy Sci. 89:4376-4386.

Terré, M., L. Castells, M. A. Khan, and A. Bach. 2015. Interaction between the physical form of the starter feed and straw provision on growth performance of Holstein calves. J. Dairy Sci. 98:1101-1109.

Terré, M., E. Pedrals, A. Dalmau, and A. Bach. 2013. What do preweaned and weaned calves need in the diet: A high fiber content or a forage source? J. Dairy Sci. 96:5217-5225.

Van Keulen, J., and B. A. Young. 1977. Evaluation of acid-insoluble ash as a natural marker in ruminant digestibility studies. J. Anim. Sci. 44:282-287.

Van Soest, P. J., J. B. Robertson, and B. A. Lewis. 1991. Methods for dietary fiber, neutral detergent fiber, and nonstarch polysaccharides in relation to animal nutrition. J. Dairy Sci. 74:3583-3597.

Weary, D. M., J. M. Huzzey, and M. A. G. von Keyserlingk. 2009 Board-invited review: Using behavior to predict and identify ill health in animals. J. Anim. Sci. 87:770-777.

Zhu, L., C. Jones, Q. Guo, L. Lewis, C. R. Stark, and S. Alavi. 2016. An evaluation of total starch and starch gelatinization methodologies in pelleted animal feed1. J. Anim. Sci. 94:1501-1507.

Zinn, R. A. 1990. Influence of flake density on the comparative feeding value of steam-flaked corn for feedlot cattle. J. Anim. Sci. 68:767-775.

Zinn, R. A., F. N. Owens, and R. A. Ware. 2002. Flaking corn: Processing mechanics, quality standards, and impacts on energy availability and performance of feedlot cattle. J. Anim. Sci. 80:1145-1156.

Žitnan, R., J. Voigt, U. Schönhusen, J. Wegner, M. Kokardova, H. Hagemeister, M. Levkut, S. Kuhla, and A. Sommer. 1998. Influence of dietary concentrate to forage ratio on the development of rumen mucosa in calves. Arch. Tierenahr. 51:279-291. 